\title{
IMAGE REFERENCES
}

All websites were last accessed on I7 July 20I9. We have taken great care to identify all rights owners. In the unlikely event that someone has been overlooked, we would kindly ask that person to contact the editors.

\section{CRYPTO ARCHITECTURE: NOTES ON MACHINE LEARNING AND DESIGN}

BY ROBERTO BOTTAZZI

FIG I: Chuanren Lin, Lei Wang, Qiuyang Zhang, Xi Meng. Fluff. Studies for a tower based on wind data. Master in Urban Design, The Bartlett, UCL, 20r6. Tutors: Roberto Bottazzi, Kostas Grigoriadis. (C) Roberto Bottazzi · FIG 2: Anna Kampani, Apostolopoulos Apostolos, Caitling Brock. Perceptive Datascapes. Diagrams showing formal transformations-based Machine Learning algorithms evaluating visual permeability. Master in Urban Design, The Bartlett, UCL, 20 18. Tutors: Roberto Bottazzi, Tasos Varoudis. (C) Roberto Bottazzi · FIG 3: Chuanren Lin, Lei Wang, Qiuyang Zhang, Xi Meng. Fluff. Studies for a tower based on wind data. Master in Urban Design, The Bartlett, UCL, 20I6. (C) Roberto Bottazzi.

II AN INSTRUMENT FOR COMMUNICATION: SELF-ORGANIZING MODEL BY NIKOLA MARINČIĆ

FIG I: Kohonen's illustration of a system which implements an ordered mapping. Image source: Teuvo Kohonen, 'Self-Organized Formation of Topologically Correct Feature Maps', Biological Cybernetics, 43.I (I982), 59-69 (60) - FIG 2: A typical representation of a self-organizing map as a visualization method based on Wikipedia featured article data. Image source: Denoir, 'Selforganizing map cartography', in Wikipedia: The Free Encyclopedia. <https://en.wikipedia.org/ wiki/Self-organizing_map\#/media/File:Self_oraganizing_map_cartography.jpg > - FIG 3: Example of Ultsch's U*Matrix of the 'Glio' data set. Image source: Ultsch, Alfred. 'U*-Matrix: A Tool to Visualize Clusters in High Dimensional Data', University of Marburg (2003), 7, accessible at: <https://pdfs.semanticscholar.org/Idgd/ba44f2d237eegd8fo388299afbccoe58162 I.pdf> - FIG 4: SOM algorithm represented in a form of Zafiris's motivic key. (C) Nikola Marinčić · FIG 5: Coexistence key of the self-organizing model. (C) Nikola Marinčić · FIG 6: Interpretation of Hjelmslev's notion of a concept within a partition spectrum. (C) Nikola Marinčić · FIG 7: The final data set after the pre-processing stage. Original images from typologie+: Innovativer Wohnungsbau, ed. by Peter Ebner et al., (Basel: Birkhäuser, 2009). () Nikola Marinčić · FIG 8: 23,393 floor plan parts on a single image. (C) Nikola Marinčić · FIG 9: I0,000 randomly chosen floor plan parts extracted from the initial data set and clustered into roo sets of actual distinctions. (C) Nikola Marinčić

\section{VOIDS, BRANDS, CHARACTERS, AND HOW TO DEAL WITH LOTS BY MIRO ROMAN}

FIG I: branding, mediating, curating, measuring, communicating, coding. (C) Miro Roman · FIG 2: A Specific Noise: Architecture. (C) Miro Roman - FIG 3: Poem for ArchDaily. (C) Miro Roman - FIG 4: Informational Encoding of Dezeen. (C) Miro Roman - FIG 5: A Cloud of Architecture. (C) Miro Roman - FIG 6: Textured Objects. (C) Miro Roman · FIg 7: Lonely Solids. @ Miro Roman · FIG 8: New Chic. (c) Miro Roman · FIG 9: Patterns. (c) Miro Roman · FIG Io: Distilled Crystals. (C) Miro Roman · FIG II: Green Garnish. (C) Miro Roman · FIG I2: Blend of the Day. (C) Miro Roman

\section{ARCHITECTURE, AN ARTIFICIAL INTELLIGENCE BY KRISTIAN FASCHINGEDER}

FIG I: The philosopher Aristippos goes ashore on the island of Rhodes and deduces the presence of people from the geometric Figures drawn in the sand. Image source: Michael Burghers: frontispiece in Ev $\lambda \lambda \varepsilon \varepsilon \delta \circ v \tau \alpha \sigma \omega \zeta o \mu \varepsilon v \alpha$. Euclidis quœ supersunt omnia ..., trans. David Gregory (Oxford, 1703). Reproduction courtesy of the British Library (shelf mark: 678.k.6))

\section{PENTECOST - A MODEL OF COMMUNICATION FOR 2 I $^{\text {ST }}$ CENTURY ARCHITECTURE BY JORGE OROZCO}

FIG I: Monads and The World. Gilles Deleuze, I993. Image source: Gilles Deleuze, The Fold: Leibniz and the Baroque, trans. by T. Conley (London: The Athlone Press, I993), 26 - Fig 2: Entropy in the case of two possibilities with probabilities $p$ and I- $p$. Claude Shannon, I948. Image source: C. E. Shannon, 'A Mathematical Theory of Communication', Bell Systems Technical Journal, 27.3 (1948), 379-423 (394) · FIG 3: Sebastiano Ricci, Mercury, Herse and Aglauros, I720-I734, oil 
on canvas, 88.5 x $58.8 \mathrm{~cm}$, Manchester Art Gallery, UK < https://artuk.org/discover/artworks/ mercury-herse-and-aglauros-205902> • FIG 4: El Greco, Pentecost, c. I596, oil on canvas, 275 X $127 \mathrm{~cm}$, Museo del Prado, Madrid, Spain <www.wikiart.org/en/el-greco/pentecost> • FIG 5: The Economist, cover, May 20 I 7. Image source: <https://www.economist.com/sites/default/files/ imagecache/400-width/print-covers/20170506_cuk40o_o.jpg>·FIG 6: Dorothy Vallens played by Isabella Rossellini in the film Blue Velvet, dir. By David Lynch (De Laurentiis Entertainment Group, I986) · FIG 7: Diagram of Church of the year 2000, Church of the year 20oo, Peter Eisenman, 1996. Image source: (CEisenman Architects, <https://eisenmanarchitects.com/Church-of-theYear-2000-1996> • FIG 8: Transcribing reality to architecture. Bernard Tschumi, I98I. Image source: Tschumi, B., The Manhattan Transcripts (London: St. Martin's Press, I98I), 50 - FIG 9: One of the three machines from Three Lessons in Architecture-The machines installation. Studio Libeskind, I985. Image source: @Libeskind <https://libeskind.com/wp-content/uploads/ memory-machine-638x650.jpg $\geq$ · FIG Io: A sourced quote in German translated to English by Yandex Translate API. (C) Jorge Orozco - FIG II: Bar chart showing the number of unique words for 43I offices. (C) Jorge Orozco - FIG I2: Vocabularies of swiss-architects and Elliot, respectively. (C) Jorge Orozco · FIG I3: Learned topics of swiss-architects and Elliot, respectively. (C) Jorge Orozco - FIG I4: Scatter plot of three different models: BoW, tf-idf and topics. Each one showing the 43I offices. (C) Jorge Orozco · FIG I5: Detail showing the same office: 'schwarz-schwarz', in three different neighbourhoods. (C) Jorge Orozco · FIG I6: Elliot Alderson and his four closest neighbouring offices. (C) Jorge Orozco

\section{CRYSTAL OF THINGS}

BY POLTAK PANDJAITAN

FIG I: shadow projection of a three-dimensional dodecahedral quasicrystal cluster. (C) Poltak Pandjaitan

\section{MYTHIC NOISE: ARCHITECTURES OF GEOLOGICAL COMMUNICATION BY ADAM NOCEK}

FIG I: The Last Angel of History, dir. John Akomfrah (Black Audio Film Collective, I996) - FIG 2: Stringing telephone wire on a tree in Enewetak Atoll, Marshall Islands, c. 1944. Image source: United States Department of Defense, c. 1944, in Wikipedia: The Free Encyclopedia, <https:// en.wikipedia.org/wiki/File:Communications_men.jpg>

\section{WHEN OTHERS PASSING BY BEHOLD: MEDIA STUDIES AND ARCHIVES ACROSS CULTURES BY MATT COHEN}

FIG. I: Theodor de Bry, 'The Marckes of sundrye of the Cheif mene of Virginia', engraving XXIII from A Briefe and True Report of the New Found Land of Virginia (Frankfurt, 1590). Courtesy of the John Carter Brown Library · FIG. 2: Theodor de Bry, 'A cheiff Lorde of Roanoac', engraving VII from A Briefe and True Report of the New Found Land of Virginia (Frankfurt, 1590). Courtesy of the John Carter Brown Library. 